\title{
Farm business success: wealth aggregation by cash flow or asset management?
}

\author{
D.A. NEAL \\ Taki Taki, Whangaehu, R.D.6, Masterton \\ daneal@xtra.co.nz
}

\begin{abstract}
Farm business success for challenge and satisfaction may include wealth aggregation. Analysis of the importance of asset management compared to production/cash flow to aggregate wealth suggests they are linked but that asset management is more lucrative. Influences on farmland prices are discussed, as well as observations of top wealth aggregators in farming.
\end{abstract}

Keywords: asset management, production/cash flow, wealth aggregation

\section{Introduction}

Farm business success - what is it all about? I suggest for many it is about challenge and satisfaction. Satisfaction is very personal, and depends on the farmer's aims and requirements. For many this includes wealth aggregation.

\section{Wealth aggregation}

Is wealth aggregation important? Initial cash income is necessary to satisfy immediate living requirements. However, beyond a relatively low threshold, extra cash is surplus to consumption. We can only eat so much food, need only so many cars, etc.

Options beyond the consumption threshold include saving and investment, usually post-tax; that is, investment in wealth. At this stage wealth is an aggregation of 'tokens', and it becomes a 'game'. Success in that 'game' provides choices and allows opportunities to be harnessed.

Common equity levels in 10 years of sheep/beef production are around $\$ 2,000,000$ and for those farming 20 years are around $\$ 4,000,000$; enviable results compared to many other career paths. Some have less equity, but some considerably more. Most of this wealth has not been aggregated through producing kilograms of product, selling that produce and paying tax.

Yet as an industry the vast majority of time, effort and resources is put into efficiently increasing the production of kilograms of saleable product. Why is this?

\section{Wealth growth - asset management or production-cash flow focus?}

To concentrate on just production and cash flow is like just viewing shares through dividends and ignoring capital gain.

\section{Asset management}

Wealth aggregation via changes in land and building values in farming is often treated as a bonus to hard work and good farming skills. However, for many, it has far out-stripped wealth aggregation from technical production and product sales. In the previous 15 years farmland values have increased from \$377356 to $\$ 1743899$, an increase multiple of 4.62 of the original value. (Figure 1).

The compounded land value increase throughout the 15 years is $10.7 \%$, compared to average cash rate of return of $2.65 \%$. (Figure 2).

New Zealand farmland value increases outpaced the Auckland housing market even when it was recently in a 'boom'. In 20 years the value of hill country sheep/beef farmland has risen from $\$ 80 / \mathrm{SU}$ to $\$ 500 / \mathrm{SU}$

Likewise in Australia, statistics based on ABARE farm surveys suggest that in the 15 years to December 2002, the total aggregate compound annual wealth growth rate is $6.5 \%$, divided between $1.4 \%$ compounded gain from cash flow, compared to $5.1 \%$ from annual compounding growth in asset value. This is despite frequent comment in Australia that there is no capital gain in Australia.

Therefore, on average, returns have been excellent, but there is a sub-group who have excelled at wealth aggregation by asset growth. These gains come from:

- Anticipation of market developments.

- Land use changes.

- Leverage into larger assets so that marginal gains are amplified across a larger portfolio.

Why is this not publicised more, and the skills required promoted more?

- Skills required are more difficult to define, benchmark and 'recipe' than technical production farming.

- The best skills are with the 'top players'; few of them teach.

- These skills are hard-earned and enormously valuable. Why teach your competitors?

- Skills and success come from experiences of being a 'player', risking your own capital, committing your own assets and feeling risk on 'the back of 
Figure 1 Average farm land values (1988-89-2001-02).

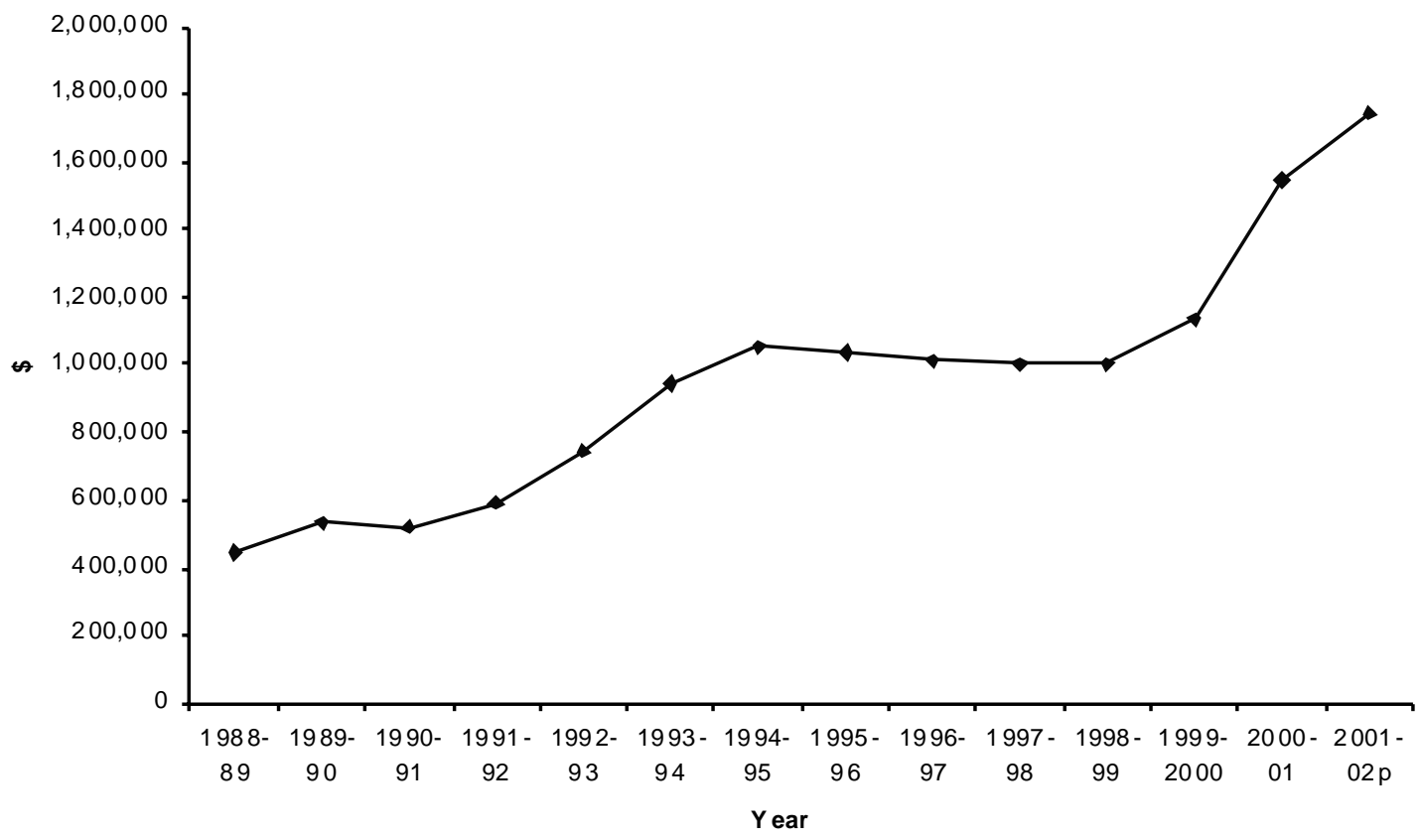

Source: MWI Economic Service. Sheep and Beef Farm Survey.

Figure 2 Rate of return.

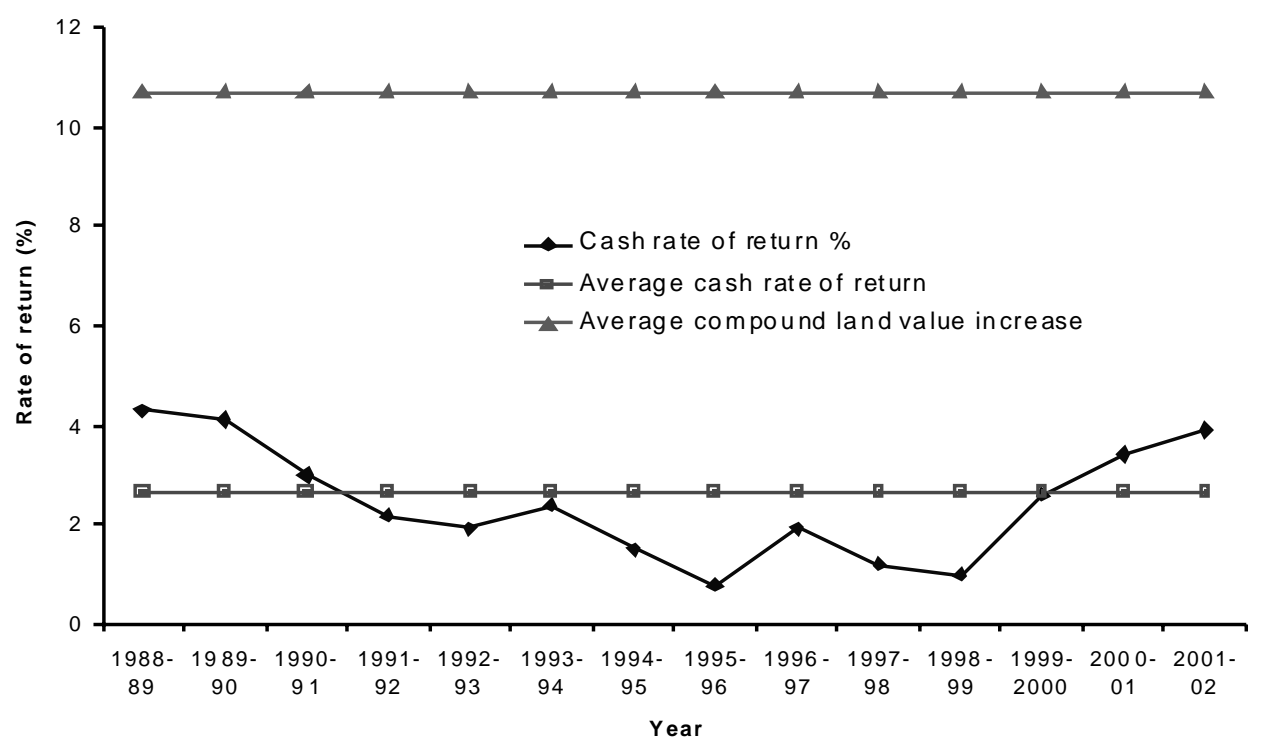

Thes e statistics are on all farm assets, whether owned or otherwise (I.e. not a retur n on equity), and are stand ardised to a single w orking owner basis.

Source: MWI Economic Service. Sheep and Beef Farm Survey. 
your own neck'.

- There is value in the intellectual property, market information and sources. Methodology is carefully guarded.

- Many industry information brokers lack understanding of this area of business. Many place it in the 'too hard basket' and are concerned that poor advice may suggest responsibility.

- As an industry there may be concern that focus and attention on this area may bring unwanted attention from government revenue seekers.

\section{Production cash flow}

Does this suggest concentration on excellence in technical production and cash flow is of low importance?

Absolutely not! Rather these skills and discipline are required as a basic prerequisite to allow the farmer to partake in the potentially more rewarding asset growth 'game'.

Excellence in technical production needs to be relentlessly pursued, and organizations like Grasslands, monitor farms and discussion groups are invaluable in that process.

For many, pursuit of these goals gives satisfaction and some part of farm business success.

Performance in the production-cash flows allows:

- Servicing of the debts necessary in asset management.

- Possible land use changes.

- Improvement in land productivity that enhances land values.

\section{Farmland prices}

Throughout history farmland prices have surged, often plateaued, occasionally slightly reduced then surged again. The timing of these cycles is difficult to predict but long-term the trend is always up. Just when, is the question.

At present, a common question being asked is "Is this as high as land prices will ever go?"

In answer the following points suggest further increases:

- Farmland is a finite resource. It is also a scarce resource in the demand-supply equation.

- Land available for farming is diminishing as farmland is absorbed for other uses.

- Growing wealth in the world will increase people's ability to pay more for scarce resources. There are few places in the world where farmland values are directly related to productive ability.

- Production from land has improved dramatically in the last 50 years and has enormous unharnessed potential to go further.
This will come from:

- Precision farming.

- Scientific advances in technical components e.g. gene technology, parasite control, cultivar improvement, fertiliser use.

- Systemising of production systems.

- Improved skilling of farmers and staff.

- Communication and information systems.

The recent increases in farmland values in New Zealand has been to do with demand-supply, change of land use, but is substantially underpinned by compounding productivity increments in the last 15 years. There is often concern that land values do not accurately reflect the returns generated. Top performing farmers generating higher rates of return can therefore afford to pay more. They frequently set market prices.

\section{Observations of top wealth aggregators in farming}

- They have a vision of where they are going and what they want to do.

- They set about achieving that vision, not seeing 'barriers', but rather 'hurdles' that need to be turned into 'stepping stones'.

- They have good networks, good contacts and keep informed in both 'wider policy' and 'street talk'.

- They make it an interest and habit to look for opportunities. They allot time to search for and assess opportunities.

- They assess risk, minimise risk but also realise that 'nothing ventured, nothing gained'.

- They associate with top players, learning and observing other successful player's skills.

- They have little interest in poor or average performers, except as potential opportunities.

- They are very competitive and respect success rather than those that just 'played'.

- They realise that they have valuable skills and intellectual property and show reluctance to let the information brokers disseminate that intellectual property into the wider community. Information provided at rare field days of these top operators is usually superficial and unrevealing.

- They take extreme care as to whom they share intellectual property and information with. Information shared is on the basis of absolute confidence and this is not negotiable.

- They 'feed-off' colleagues' enthusiasm and success.

- They have a clear understanding of the 'profitdrivers' in their business. They tend to keep those 'drivers' simple.

- They pursue technological production and cash 
flow management enthusiastically and relentlessly.

- They minimise problems, but if problems do occur they deal with them promptly and professionally, and move on.

- They do not mind hard work and time input.

- They have a sense of timing.

- They run 'tight' businesses that are well developed and have skilled, motivated staff that work as a team.

\section{Conclusion}

Farm business success can only be measured against the aims of the principals. Aims may correctly prioritise mental and physical health.

If they also include wealth aggregation then clear understanding is required of the relative importance of production/cash flow versus asset management.

Emphasis has long been placed on the production/ cash flow sector of farming for various reasons, when the main wealth aggregation has occurred in asset management.

Clever asset management can dramatically enhance wealth creation. The potential rewards are large.

Relatively little industry effort is focused on improving these skills for various reasons.

Wealth creation from both industry and the individual farmer perspective is important. Perhaps the industry and associated servicing organizations need to apply more focus and resources in this area. 